\title{
Rare Earth and Trace Elements Distribution in Sediments of River Gora, Minna Area, North-Central Nigeria: Implication for Provenance
}

\author{
S. O. Obaje ${ }^{1}$, I. A. Akpoborie ${ }^{2}$, F. C. Ugbe $^{2} \&$ A. Onugba ${ }^{1}$ \\ ${ }^{1}$ Department of Earth Sciences, Salem University, P.M.B. 1060, Lokoja, Nigeria \\ ${ }^{2}$ Department of Geology, Delta State University, P.M.B. 1, Abraka, Nigeria \\ Correspondence: S. O. Obaje, Department of Earth Sciences, Salem University, P.M.B. 1060, Lokoja, Nigeria. \\ Tel: 234-805-776-3868. E-mail: isolobaje2004@yahoo.com
}

Received: December 3, $2014 \quad$ Accepted: December 16, $2014 \quad$ Online Published: January 20, 2015
$\begin{aligned} & \text { doi:10.5539/esr.v4n1p103 } \\ & \text { URL: http://dx.doi.org/10.5539/esr.v4n1p103 }\end{aligned}$

\begin{abstract}
Rare earth and trace elemental compositions of sediment samples collected from the bed of the River Gora in the Minna area of north-central Nigeria were determined with X-Ray Fluorescence spectrometry. Statistical analyses of the results indicate that spatial variations of $\mathrm{La}, \mathrm{Ce}, \mathrm{Nd}, \mathrm{Sc}, \mathrm{Y}, \mathrm{Eu}, \mathrm{Mo}, \mathrm{Zr}, \mathrm{Pb}$, and $\mathrm{Co}$ and the Pearson positive correlation of $\mathrm{La} / \mathrm{Yb}, \mathrm{Ce} / \mathrm{Ce} *, \mathrm{Eu} / \mathrm{Eu}$ * $\mathrm{LREE} / \mathrm{HREE}$ in addition to the normalized Chondrite plot of the rare earth elements area revealed a possible environment high erosivity, terrigenous fluviatile sediment sources and lithologically controlled distribution from crystalline Basement source rock. This is further supported by the positive $\mathrm{Eu} / \mathrm{Eu}^{*}$ anomaly that is indicative of subdued anthropogenic influence. The $\mathrm{Ce} / \mathrm{Ce}{ }^{*}$ positive anomaly also revealed a two-component system of fine- and coarse- grained terrigenous input. Principal component analysis using rotation solution revealed three sources that are possibly responsible for the distribution of REEs and trace elements. The analyses have also been interpreted to show that HREE, $\mathrm{Rb}, \mathrm{Zr}, \mathrm{Y}$ and $\mathrm{Nb}$ were derived from geogenic source resulting from weathering, while $\mathrm{Cr}, \mathrm{Co}, \mathrm{Ni}$ and $\mathrm{Zn}$ also came from geogenic source via adsorption by clay minerals in the stream sediments. On the other hand, LREE, REE, $\mathrm{Ni}, \mathrm{V}$ and $\mathrm{Cr}$ were interpreted to be from lithogenic source, while $\mathrm{Zn}, \mathrm{Pb}$ and $\mathrm{As}$ came from both lithogenic and anthropogenic sources.
\end{abstract}

Keywords: rare earth element, trace element, provenance, River Gora, Minna, Nigeria

\section{Introduction}

REEs and trace elements share certain unique physico-chemical properties that render them useful for near surface environment geochemical studies. It has been established that REEs in terrigenous sediments are exceptionally unreactive, thus making them very useful for provenance studies. Sediments, especially in rivers are sources of transportation and sinks for REEs and trace elements (McLennan, 1989). The fractionation of REEs and trace elements takes place in solid state phase. In this paper, information from REEs and trace elements distribution will be used to decipher the prevailing physico-chemical conditions and probable source rocks of the sediments of the River Gora. The main aim of this study is to investigate the distribution of rare earth and trace elements in river sediments with respect to their provenance. To achieve this, twenty-four locations were sampled and composited into twelve samples for laboratory analysis. In addition to determining the provenance of the rare earth and trace elements, this study will contribute to a better understanding of the geology of the region as well as serve as an important input to the review of the published geological map of the Minna area.

\subsection{Description of Area of Study}

The study area lies between latitude $9^{0} 33^{\prime} \mathrm{N}$ and $9^{0} 34^{\prime} \mathrm{N}$ and longitude $6^{0} 34^{\prime} \mathrm{E}$ and $6^{0} 35^{\prime} \mathrm{E}$ in Minna area of north-central Nigeria. Accessibility to the sampling locations is via Chanchaga-Tegina road, minor roads, footpaths and the river channel (Fig. 1). The area is typical "guinea woodland savannah" (Iloeje, 1991) which consists of tall grasses, shrub and scattered trees with denser tree cover along drainage channels. Cotton and sugar cane plantations are predominant in this area of undulating and rolling high hills and valleys. The highest elevation within the area is about 240 meters above mean sea level. The area is drained principally by River Gora and other minor ephemeral streams. 


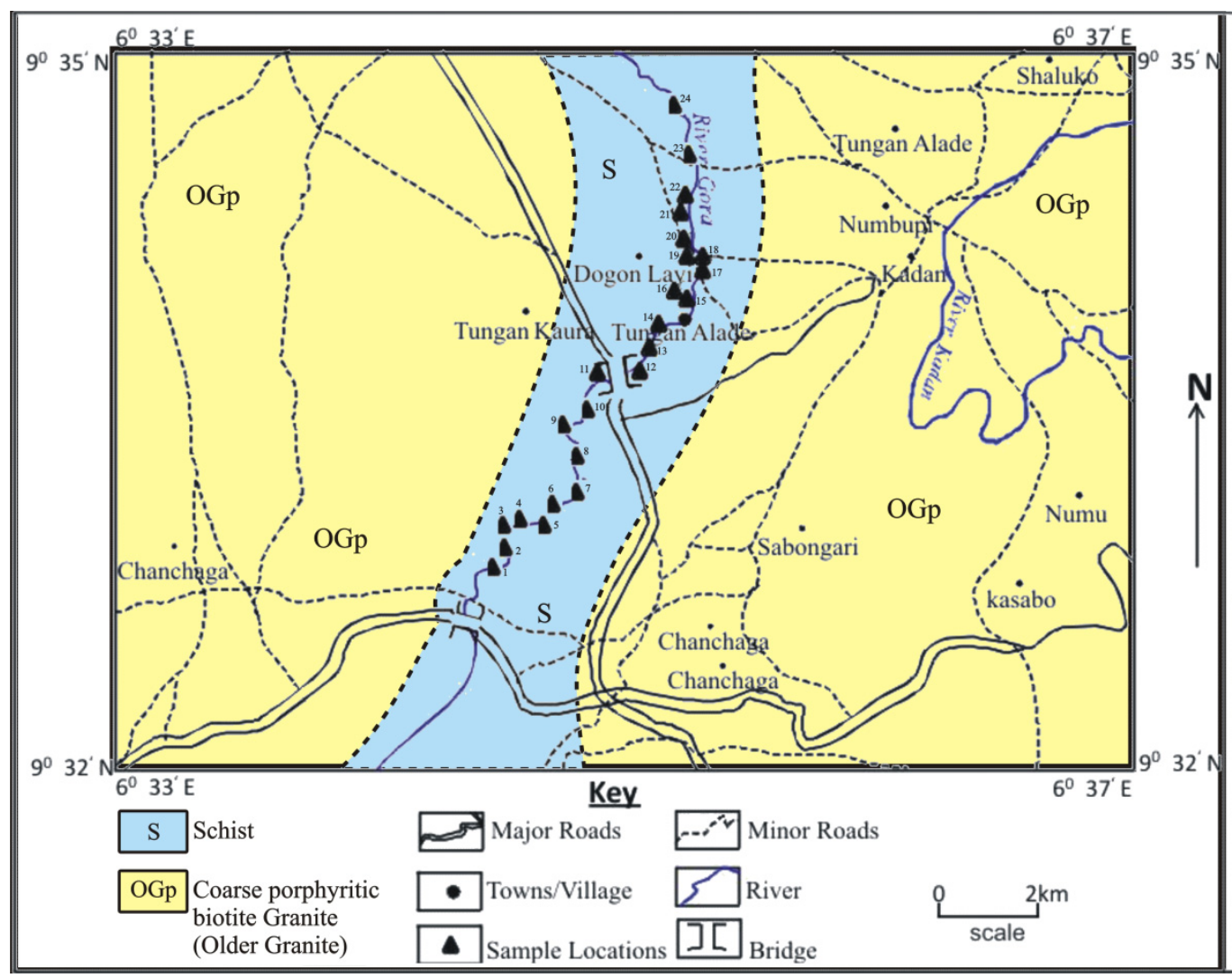

Figure 1. Geological map of study area

\subsection{Geology of Study Area}

The study area is underlain by the Precambrian Basement Complex of north-central Nigeria. The Basement Complex is one of the three major litho-stratigraphic components of the geology of Nigeria. The Nigerian Basement Complex forms a part of the Pan-African mobile belt and lies between the West African and Congo cratons and the Tuareg shield (Black, 1980; Grant et al., 1969). It is intruded by the Mesozoic calc-alkaline ring complexes (Younger Granites) of the Jos Plateau and unconformably overlain by Cretaceous to Recent sediments. The Nigerian Basement Complex was affected by the Pan-African $(600 \pm 150 \mathrm{Ma})$ orogeny and occupies the reactivated region which resulted from plate collision between the passive continental margin of the West African craton and the active Pharusian continental margin (Burke and Dewey, 1972). The Basement rocks are believed to be the results of at least four major orogenic cycles of deformation, metamorphism and remobilization corresponding to the Liberian $(2,800 \pm 200 \mathrm{Ma})$, the Eburnean $(2,000 \pm 200 \mathrm{Ma})$, the Kibaran $(1,100 \pm 200 \mathrm{Ma})$, and the Pan-African cycles $(600 \pm 150 \mathrm{Ma})$. The first three cycles were characterized by intense deformation and isoclinals folding accompanied by regional metamorphism, which was further followed by extensive migmatization. The Pan-African deformation was accompanied by regional syntectonic granites and gneisses. Late tectonic emplacement of granites and granodiorites and associated contact metamorphism accompanied the end stages of this last deformation. The end of the orogeny was marked by faulting and fracturing (Gandu et al., 1986). Within the Basement Complex of Nigeria, four major units are distinguishable, namely: migmatite-gneiss-quartzite complex, schist belts, Pan-African granitoids, and undeformed acid and basic dykes (Dada, 2006). The dominant lithologic units in River Gora area are schist and coarse porphyritic biotite granite also called Older Granite. Several quartz veins cross-cut the schists in the area.

\section{Methods}

The work was accomplished through both field and laboratory techniques of sampling, sample preparation and analysis. The fieldwork involved the collection of stream sediments. Twenty-four stream sediment samples were taken at depths of $30-50 \mathrm{~cm}$ in the river bed. Sample preparation via dry sieving was carried out in the Department of Geology Laboratory of the Delta State University, Abraka, south-southern Nigeria. $10 \mathrm{~g}$ from 63 $\mu \mathrm{m}$ fractions of each sample were taken to the National Geochemical Laboratory of the Nigerian Geological Survey Agency in Kaduna, north-western Nigeria for X-Ray Fluorescence spectrometric (XRF) analysis. 
The twenty-four stream sediment samples were composited into twelve and crushed to less than 63 microns with the aid of a Tema vibrating mill before sieving to $60 \mu \mathrm{m}$. 5 grams of the dry sample was weighed in the silica crucible and then ignited in the furnace at $1,000{ }^{\circ} \mathrm{C}$ for 2 to 3 hours for the calcination of impurities in the sample powder. Thereafter, samples were removed from the furnace and allowed to cool to room temperature in desiccators. Each ignited sample powder was weighed again to determine the weight of calcinated impurities which were $\mathrm{H}_{2} \mathrm{O}^{-}, \mathrm{H}_{2} \mathrm{O}^{+}$and $\mathrm{CO}_{2} .1$ gram of stored ignited sample powder and exactly 5 times of flux (x-ray flux-type) 66\%:34\% (66\% lithium tetraborate: 34\% lithium metaborate) was added to lower the vitrification temperature. The weighed mixture was properly mixed in a Platinum dish and ignited in the pre-set furnace (Eggon-2 Automatic Fuse Bead Maker) at $1,500{ }^{\circ} \mathrm{C}$ for 10 minutes to form glass bead. Each glass bead was labeled and slotted into the computerized XRF (Epsilon-5 Panalytical model). The REEs and trace elemental analysis was carried out using compressed powder pellets. The pellets were prepared by weighing 3 grams of oven-dried samples and 3 grams flux (cellulose-powder) added as a binder and dispersive agent and shaken in small plastic containers for 12 minutes. The appropriately blended mixture was then compressed by applying pressure of $1,500 \mathrm{kgm}^{-2}$ using both manual and electronic compressors. The pellets were placed in the computer programmed X-Ray Fluorescence spectrometer (XRF) and the conditions for trace elemental analysis were set to give the result in part per million (ppm).

\section{Results and Discussion}

\subsection{Rare Earth Elements}

Table 1 displays the rare earth elements (REEs) concentrations in the samples, while Table 2 shows CI-Chondrite concentrations given by McLennan (1989) and Barat et al. (2012). Table 3 shows the Chondrite normalized values, while Table 4 shows calculated total concentrations of the REE and some REE ratios. Table 1 shows that HREEs are enriched by factor range of 0.88 to 2.19 with mean value of 1.23 in comparison to LREEs in all samples (Fig. 2). On the other hand, CI-Chondrite normalized values indicate $\sum$ (HREE)n enrichment with factor in range of 5.07 to 7.61 with mean value of 5.91 in comparison to $\sum$ (LREE)n. The distribution trend revealed that $\sum$ (HREE)n have high average concentration in the midstream and upstream areas in comparison to the downstream area. On the other hand, $\sum$ (LREE)n and $\sum$ (REE)n have their highest average concentrations upstream and their lowest average values downstream (Table 4, Figs. 2-4). Eu/Eu* has its highest average concentration midstream, while $(\mathrm{La} / \mathrm{Yb}) n$ has high average values downstream and upstream. $\mathrm{Ce} / \mathrm{Ce}$ * has highest average concentration upstream in comparison to its average downstream values. According to Ramesh et al. (2000), Ce anomalies are associated with the formation of $\mathrm{Ce}^{4+}$ and stable Ce-hydroxides. The enriched REEs are indicative of felsic source rocks in agreement with McLennan (1989). Lower stream velocity may be responsible for the high degree of fractionation between LREEs and HREEs noticed in their distribution (Table 1, Figs. 2-4). According to Ramesh et al. (2000), enrichment of REEs reflects the intense silicate weathering of crustal materials and their subsequent deposition in stream sediments. The $\sum$ (LREE)n/ $/$ (HREE)n ratios vary from 0.08 to 0.34 with mean ratio of 0.18 (Table 4$)$. ( $(\mathrm{aa} / \mathrm{Yb}) \mathrm{n}$ ratios range from 0.56 to 3.38 with mean ratio of 2.01 (Table 4, Fig. 3) and that indicates high erosional rates. The result suggests that La was removed from crustal source via weathering process, transported and deposited by the streams. Physical weathering is predominant in fine-grained sediments, thus it may be inferred that REEs intense fractionation took place in River Gora (Ramesh et al., 2000). The low ratio of $\mathrm{La} / \mathrm{Yb}$ in location GRS7 suggests the presence of coarse-grained sediments with reference to the findings of McLennan (1988). The high concentration of HREE and $\mathrm{La} / \mathrm{Yb}$ indicates crystalline Basement source rocks for the samples. The negative correlation of $\mathrm{Y}$ with REEs indicates its absence in detrital association.

The ratios of $\mathrm{Ce} / \mathrm{Ce}^{*}$ and $\mathrm{Eu} / \mathrm{Eu}^{*}$ and their patterns are given in Table 4 and Figs. 3 and 5. Ce occurs as $\mathrm{Ce}^{3+}$ and $\mathrm{Ce}^{4+}$, while $\mathrm{Eu}$ occurs as $\mathrm{Eu}^{2+}$ and $\mathrm{Eu}^{3+}$. The occurrence of $\mathrm{Ce}$ and $\mathrm{Eu}$ in two oxidation states distinguish them from the other trivalent REEs, especially under oxygenated conditions (Piper, 1974). Variation in Ce anomalies is indicative of terrigenous input, depositional environment and diagenetic conditions. $\mathrm{Ce} / \mathrm{Ce} *>1$ and $<1$ designate positive and negative anomalies, respectively (Toyoda et al., 1990). Ce/Ce* ratio range of 5.01 to 32.58 with mean ratio of 17.96 confirmed abundant terrigenous input in an alkaline reducing environment. On the other hand, negative $\mathrm{Ce} / \mathrm{Ce}^{*}$ is indicative of oxic environment in a river with input of terrigenous clay and coarser grains.

$\mathrm{Eu} / \mathrm{Eu}^{*}$ ratios are $>1$ in all the samples (Table 4, Figs. 3 and 5) suggesting felsic source rocks probably the Pan-African granitoids of the Minna area through which the river drains downward to study area. The positive $\mathrm{Eu}$ anomalies suggest intense weathering of the source rocks. The results revealed higher Eu anomalies in the midstream in comparison to the downstream and upstream (Table 4, Figs. 3 and 5). 
The high REEs concentration in the study area revealed probability of an alkaline and low carbonate content environment (Ramesh et al. 2000) that favored immobility and resultant enrichment of the REEs.

\subsection{Trace Elements}

Table 5 shows the trace elements concentrations in the samples together with their background/baseline values in the upper continental crust. $\mathrm{V}, \mathrm{Cu}, \mathrm{Mo}$ and $\mathrm{Zr}$ have mean concentrations higher than the average crustal values reported (Table 5).

Table 1. REE concentrations in the samples analyzed

\begin{tabular}{|c|c|c|c|c|c|c|c|c|c|c|c|}
\hline SLN & Stream Course & $\mathrm{La}$ & $\mathrm{Ce}$ & $\mathrm{Nd}$ & $\mathrm{Sc}$ & $\mathrm{Eu}$ & $\mathrm{Gd}$ & $\mathrm{Yb}$ & $\mathrm{Y}$ & $\sum$ LREE & $\sum \mathrm{HREE}$ \\
\hline GRS1 & & 16 & 9 & 4 & 6 & 17 & 24 & 4 & 19 & 35 & 64 \\
\hline GRS2 & & 6 & 4 & 6 & 5 & 28 & 15 & 2 & 11 & 21 & 56 \\
\hline GRS3 & Downstream & 14 & 13 & 9 & 7 & 11 & 26 & 4 & 20 & 43 & 61 \\
\hline GRS4 & & 11 & 14 & 11 & 7 & 36 & 17 & 3 & 8 & 43 & 64 \\
\hline GRS5 & & 5 & 8 & 5 & 9 & 31 & 9 & 2 & 7 & 27 & 49 \\
\hline GRS6 & & 18 & 9 & 7 & 8 & 35 & 8 & 4 & 12 & 42 & 59 \\
\hline GRS7 & Midstream & 14 & 21 & 14 & 16 & 31 & 11 & 16 & 8 & 65 & 66 \\
\hline GRS8 & & 7 & 19 & 11 & 14 & 30 & 9 & 3 & 5 & 51 & 47 \\
\hline GRS9 & & 9 & 9 & 5 & 9 & 28 & 21 & 2 & 16 & 32 & 67 \\
\hline GRS10 & Upstream & 18 & 18 & 20 & 11 & 34 & 13 & 11 & 7 & 67 & 65 \\
\hline GRS11 & & 16 & 26 & 16 & 14 & 31 & 17 & 9 & 7 & 72 & 64 \\
\hline GRS12 & & 21 & 22 & 21 & 12 & 24 & 9 & 4 & 9 & 76 & 46 \\
\hline MEAN & & 12.92 & 14.33 & 10.75 & 9.83 & 28 & 14.92 & 5.33 & 10.75 & 47.83 & 59 \\
\hline MIN & & 5 & 4 & 4 & 5 & 11 & 8 & 2 & 5 & 21 & 46 \\
\hline MAX. & & 21 & 26 & 21 & 16 & 36 & 26 & 16 & 20 & 76 & 67 \\
\hline
\end{tabular}

Table 2. Rare earth elements and their Chondrite Concentration (after McLennan, 1989; Barat et al., 2012)

\begin{tabular}{|c|c|c|}
\hline $\mathrm{S} / \mathrm{NO}$ & REE & ORDINARY AND CI-CHONDRITE (ppm) \\
\hline 1. & Scandium $(\mathrm{Sc})$ & 5.58 \\
\hline 2. & Yttrium (Y) & 1.56 \\
\hline 3. & Lanthanum (La) & 0.325 \\
\hline 4. & Cerium $(\mathrm{Ce})$ & 0.798 \\
\hline 5. & Praeseodymium (Pr) & 0.122 \\
\hline 6. & Neodymium (Nd) & 0.567 \\
\hline 7. & Promethium (Pm) & \\
\hline 8. & Samarium (Sm) & 0.186 \\
\hline 9. & Europium (Eu) & 0.0692 \\
\hline 10. & Gadolinium (Gd) & 0.255 \\
\hline 11. & Terbium (Tb) & 0.047 \\
\hline 12. & Dysprosium (Dy) & 0.305 \\
\hline 13. & Holmium (Ho) & 0.070 \\
\hline 14. & Erbium (Er) & 0.209 \\
\hline 15. & Thulium (Tm) & 0.03 \\
\hline 16. & Ytterbium (Yb) & 0.209 \\
\hline 17. & Lutetium (Lu) & 0.0349 \\
\hline
\end{tabular}

Table 3. Chondrite Normalized REE values (ppm) in River Gora Sediments

\begin{tabular}{ccrrrrrrrr}
\hline LNO. & Stream Course & $(\mathrm{La}) \mathrm{n}$ & $(\mathrm{Ce}) \mathrm{n}$ & $(\mathrm{Nd}) \mathrm{n}$ & $(\mathrm{Sc}) \mathrm{n}$ & $(\mathrm{Eu}) \mathrm{n}$ & $(\mathrm{Gd}) \mathrm{n}$ & $(\mathrm{Yb}) \mathrm{n}$ & $(\mathrm{Y}) \mathrm{n}$ \\
\hline GRS1 & & 49.23 & 11.28 & 7.055 & 3.85 & 245.67 & 94.12 & 19.14 & 3.25 \\
GRS2 & & 18.46 & 5.01 & 10.58 & 3.21 & 404.62 & 58.82 & 9.57 & 1.88 \\
GRS3 & \multirow{2}{*}{ Downstream } & 43.08 & 16.29 & 15.87 & 4.49 & 158.96 & 101.96 & 19.14 & 3.42 \\
GRS4 & & 33.85 & 17.54 & 19.40 & 4.49 & 520.23 & 66.67 & 14.35 & 1.37 \\
GRS5 & \multirow{2}{*}{ Midstream } & 15.39 & 10.03 & 8.82 & 5.77 & 447.98 & 35.29 & 9.57 & 1.20 \\
GRS6 & & 55.39 & 11.28 & 12.35 & 5.13 & 505.78 & 31.37 & 19.14 & 2.05 \\
\hline
\end{tabular}




\begin{tabular}{|c|c|c|c|c|c|c|c|c|c|}
\hline GRS7 & & 43.08 & 26.32 & 24.69 & 10.26 & 447.98 & 43.14 & 76.56 & 1.37 \\
\hline GRS8 & & 21.54 & 23.81 & 19.40 & 8.97 & 433.53 & 35.29 & 14.35 & 0.86 \\
\hline GRS9 & & 27.70 & 11.28 & 8.82 & 5.77 & 404.62 & 82.35 & 9.57 & 2.74 \\
\hline GRS10 & & 55.39 & 22.56 & 35.27 & 7.05 & 491.33 & 50.98 & 52.63 & 1.20 \\
\hline GRS11 & Upstream & 49.23 & 32.58 & 28.22 & 8.97 & 447.98 & 66.67 & 43.06 & 1.20 \\
\hline GRS12 & & 64.62 & 27.57 & 37.04 & 7.69 & 346.82 & 35.29 & 19.14 & 1.54 \\
\hline MEAN & & 39.74 & 17.96 & 18.96 & 6.30 & 404.62 & 58.50 & 25.52 & 1.84 \\
\hline MIN. & & 15.39 & 5.01 & 7.06 & 3.21 & 158.96 & 31.37 & 9.57 & 0.86 \\
\hline MAX. & & 64.62 & 32.58 & 37.04 & 10.26 & 520.23 & 101.96 & 76.56 & 3.42 \\
\hline
\end{tabular}

Table 4. Total REE values and some REE ratios in River Gora Sediments

\begin{tabular}{llrrrrrrr}
\hline LNO. & $\begin{array}{l}\text { Stream } \\
\text { Course }\end{array}$ & $\sum$ (LREE)n & $\sum$ (HREE)n & $\sum$ (REE)n & $\begin{array}{l}\sum \text { (LREE)n/ } \Sigma \\
\text { (HREE)n }\end{array}$ & $\mathrm{Ce} / \mathrm{Ce}{ }^{*}$ & $\begin{array}{c}\mathrm{Eu} / \mathrm{Eu} * \\
\text { (La/ } \\
\text { Yb)n }\end{array}$ \\
\hline GRS1 & & 71.41 & 362.17 & 433.58 & 0.20 & 11.28 & 245.67 & 2.57 \\
GRS2 & & 37.26 & 474.90 & 512.16 & 0.08 & 5.01 & 404.62 & 1.93 \\
GRS3 & & 79.73 & 283.48 & 363.21 & 0.28 & 16.29 & 158.96 & 2.25 \\
GRS4 & Downstream & 75.28 & 602.62 & 677.90 & 0.13 & 17.54 & 520.23 & 2.34 \\
GRS5 & & 39.10 & 494.04 & 534.03 & 0.08 & 10.03 & 447.98 & 1.61 \\
GRS6 & & 84.14 & 558.34 & 642.48 & 0.15 & 11.28 & 505.78 & 2.89 \\
GRS7 & & 104.34 & 569.04 & 673.38 & 0.18 & 26.32 & 447.98 & 0.56 \\
GRS8 & Midstream & 73.72 & 484.03 & 557.75 & 0.15 & 23.81 & 433.53 & 1.50 \\
GRS9 & & 53.56 & 499.28 & 552.84 & 0.11 & 11.28 & 404.62 & 2.89 \\
GRS10 & & 120.27 & 596.14 & 716.40 & 0.20 & 22.56 & 491.33 & 1.05 \\
GRS11 & & 119.01 & 558.90 & 677.91 & 0.21 & 32.58 & 447.98 & 1.14 \\
GRS12 & Upstream & 136.91 & 402.79 & 539.71 & 0.34 & 27.57 & 346.82 & 3.38 \\
MEAN & & 82.97 & 490.48 & 573.45 & 0.18 & 17.96 & 404.62 & 2.01 \\
MIN. & 37.26 & 283.48 & 363.21 & 0.08 & 5.01 & 158.96 & 0.56 \\
MAX. & 71.41 & 362.17 & 716.40 & 0.34 & 32.58 & 520.23 & 3.38 \\
\hline
\end{tabular}

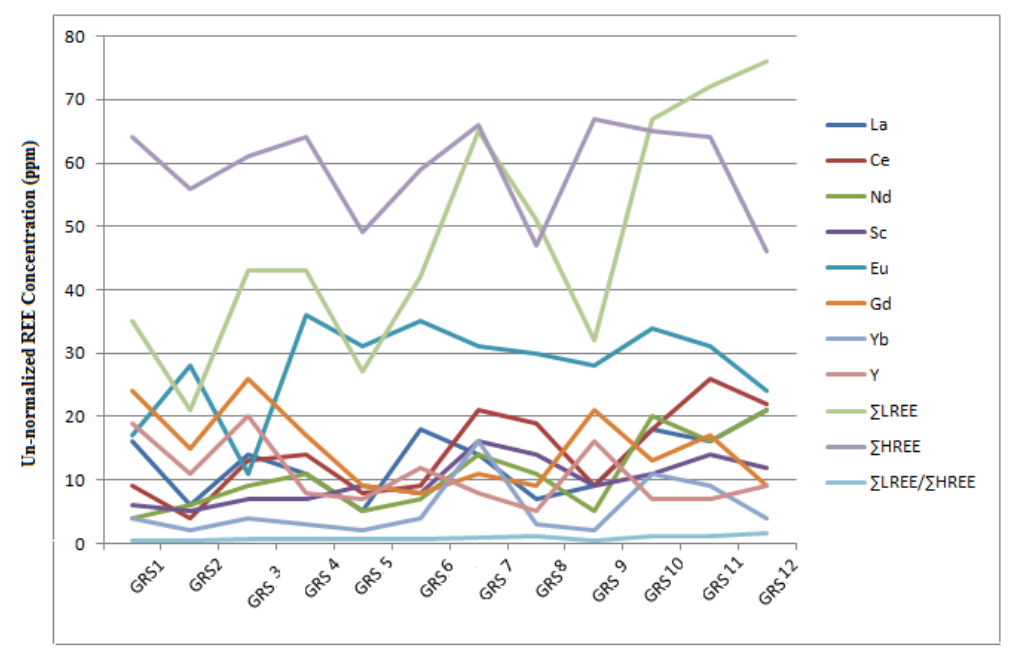

Sample Location Point

Figure 2. Chondrite un-normalized REEs Distribution in River Gora Sediments 


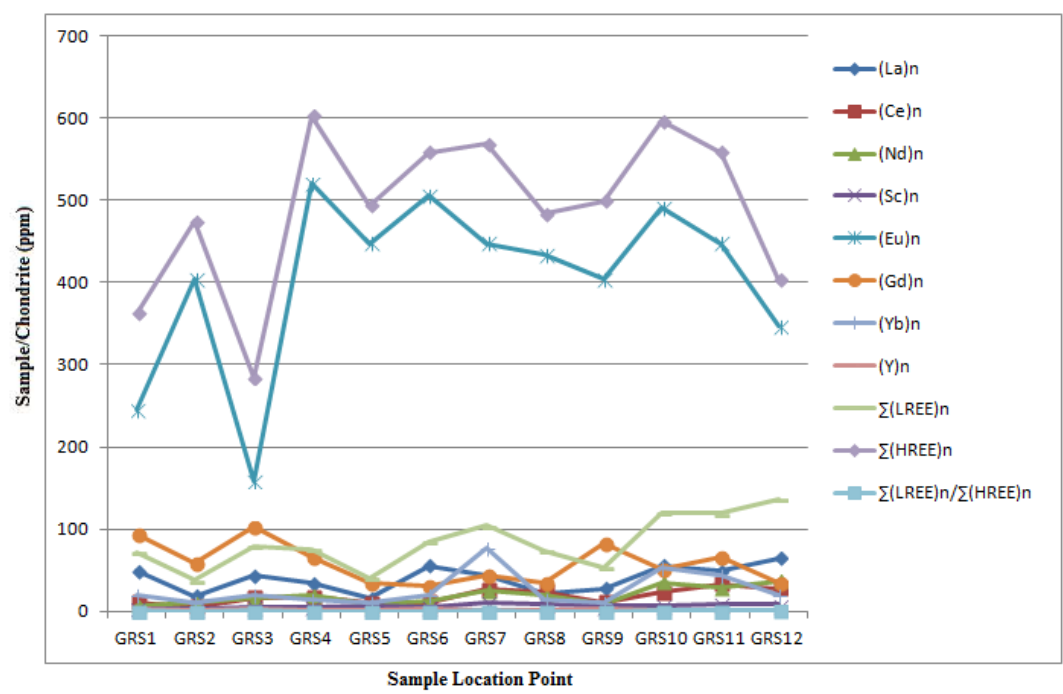

Figure 3. Chondrite normalized REEs Distribution in River Gora Sediments

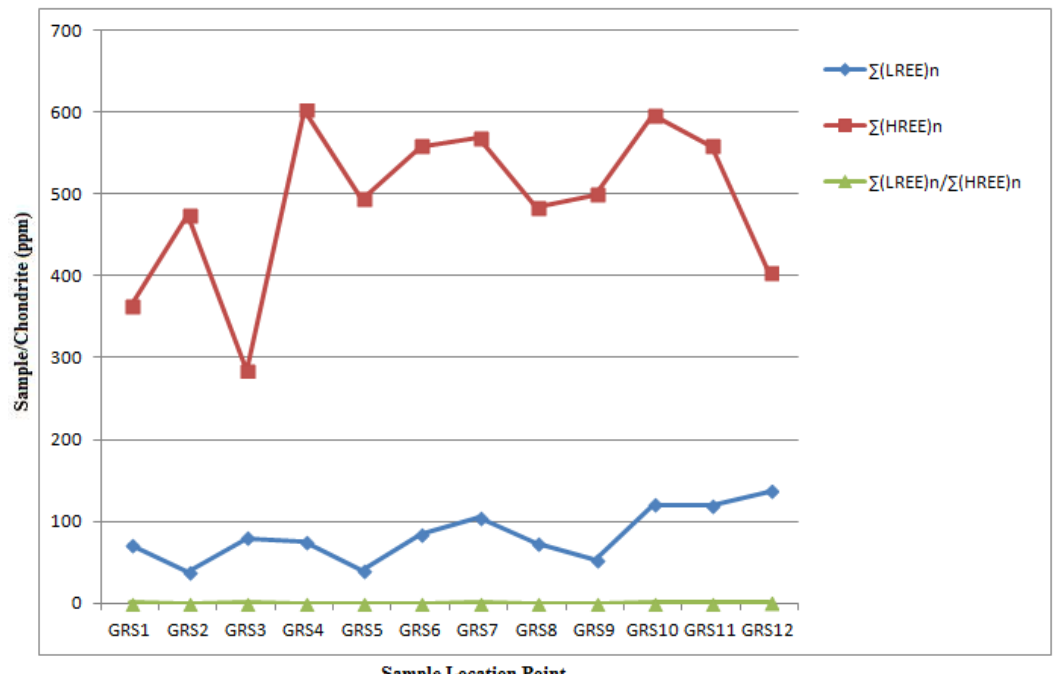

Figure 4. $\sum$ (LREE)n and $\sum$ (HREE)n Distribution in River Gora Sediments

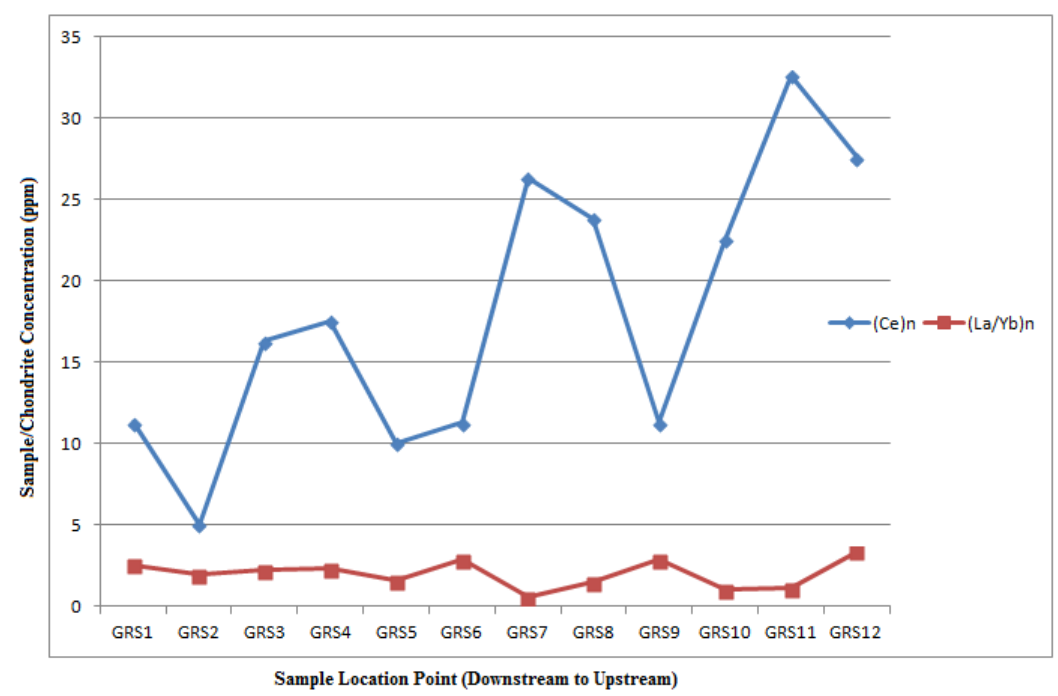

Figure 5. Distribution of Normalized La/ $\mathrm{Yb}$ and $\mathrm{Ce}$ in River Gora Sediments 


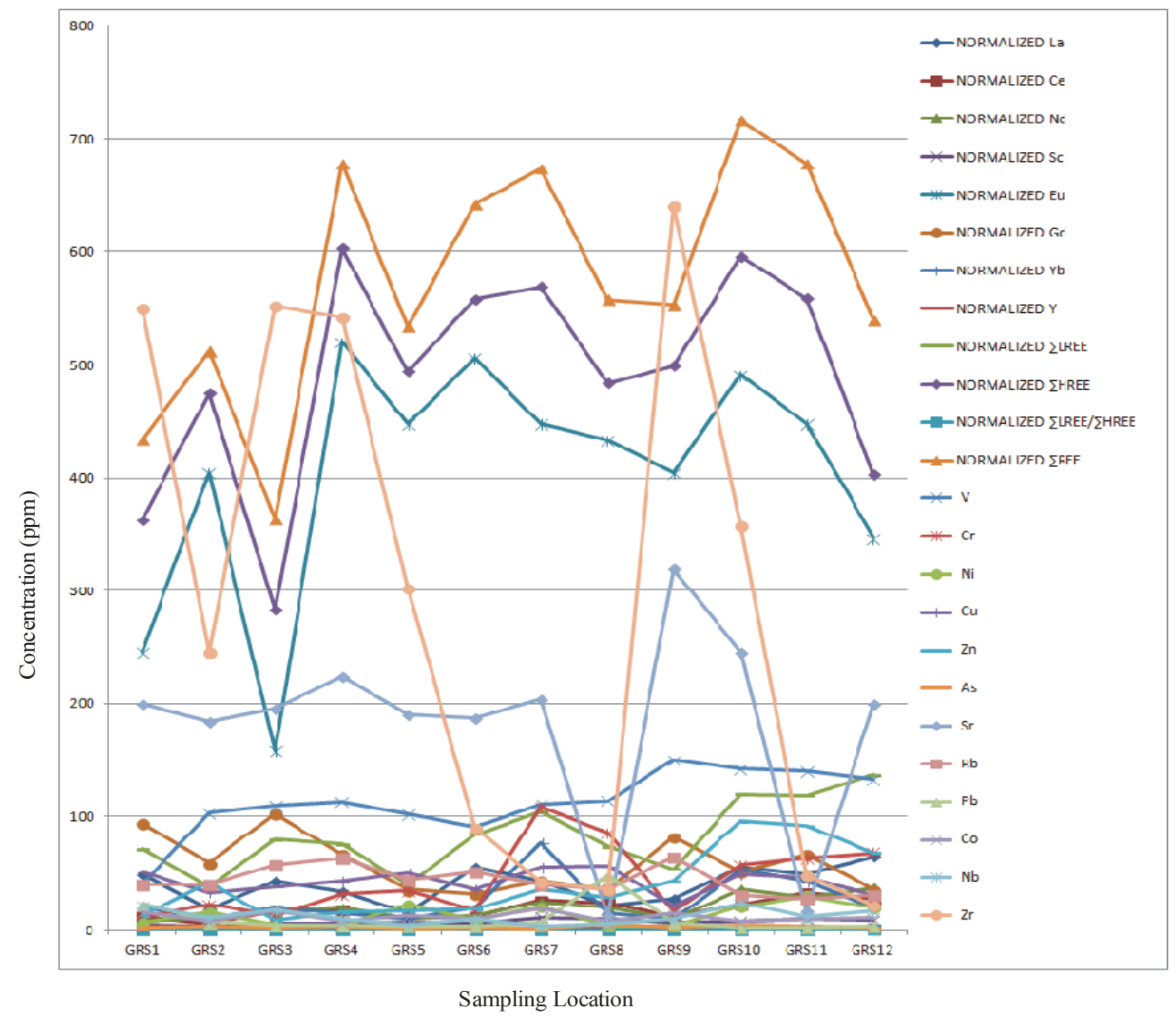

Figure 6. Downstream to Upstream Spatial Distribution of Rare Earth and Trace Elements in River Gora Sediments.

Table 5. Statistical Summary of Trace Elements concentrations in comparison to published Upper Crust Concentrations (in ppm). $\mathrm{n}=12$

\begin{tabular}{lrrrrrrrr}
\hline \multirow{2}{*}{ Element } & \multicolumn{4}{c}{ This Study } & \multicolumn{4}{c}{ Upper Continental Crust } \\
\cline { 2 - 9 } & Min. & Max. & Mean & Std. Dev. & \multicolumn{1}{c}{ A } & \multicolumn{1}{c}{ B } & \multicolumn{1}{c}{ C } & \multicolumn{1}{c}{ D } \\
\hline $\mathrm{V}$ & 40.00 & 150.00 & 112.33 & 29.22 & 98.00 & 107.00 & 53.00 & 97.00 \\
$\mathrm{Cr}$ & 10.00 & 108.00 & 43.87 & 32.12 & 80.00 & 85.00 & 35.00 & 92.00 \\
$\mathrm{Ni}$ & 3.00 & 30.00 & 12.75 & 9.35 & 38.00 & 44.00 & 19.00 & 47.00 \\
$\mathrm{Cu}$ & 21.00 & 56.00 & 42.42 & 10.74 & 32.00 & 25.00 & 14.00 & 28.00 \\
$\mathrm{Zn}$ & 8.00 & 96.00 & 39.58 & 30.55 & 70.00 & 71.00 & 52.00 & 67.00 \\
$\mathrm{As}$ & 1.00 & 5.00 & 2.50 & 1.17 & 4.40 & 1.50 & 2.00 & 4.80 \\
$\mathrm{Sr}$ & 12.00 & 319.00 & 181.5 & 86.60 & 266.00 & 350.00 & 316.00 & 320.00 \\
$\mathrm{Mo}$ & 0.50 & 21.00 & 4.75 & 2.13 & 0.78 & 1.50 & 1.40 & 1.10 \\
$\mathrm{Rb}$ & 28.00 & 64.00 & 43.75 & 12.37 & 82.00 & 112.00 & 110.00 & 84.00 \\
$\mathrm{~Pb}$ & 2.00 & 48.00 & 9.25 & 13.47 & 18.00 & 17.00 & 17.00 & 17.00 \\
$\mathrm{Co}$ & 7.00 & 18.00 & 10.92 & 3.97 & 17.00 & 17.00 & 12.00 & 17.30 \\
$\mathrm{Nb}$ & 3.00 & 23.00 & 11.42 & 6.50 & 12.00 & 12.00 & 26.00 & 12.00 \\
$\mathrm{Zr}$ & 21.00 & 640.00 & 285.58 & 238.49 & 188.00 & 190.00 & 237.00 & 193.00 \\
\hline
\end{tabular}

A: Gao et al. (1975); B: Taylor and McLennan (1985, 1995); C: Wedepohl (1995); D: Rudnick and Gao (2003).

The average concentrations of $\mathrm{V}, \mathrm{Cu}, \mathrm{Mo}$ and $\mathrm{Zr}$ are above their average crustal values, while the average concentrations of $\mathrm{Cr}, \mathrm{Ni}, \mathrm{Zn}, \mathrm{As}, \mathrm{Sr}, \mathrm{Rb}, \mathrm{Pb}$ and $\mathrm{Co}$ are less than their average upper continental crustal values (Table 5). On the other hand, the average concentration of $\mathrm{Nb}$ is approximate to its average crustal value. The reason for the average concentration differences with the average crustal values is probably due to intense weathering of the Pan-African granitoids in the study area, which had been reported by Key et al. (2012) as a 
major factor for the enrichment of $\mathrm{Zr}$ in the Minna area of north-central Nigeria. Fig. 6 shows spatial concentration patterns of rare earth and trace elements in the study area. The spatial distribution of the trace elements in the study area is shown in Fig. 7. V, Cr, Ni, Cu, $\mathrm{Zn}, \mathrm{As}, \mathrm{Mo}, \mathrm{Rb}, \mathrm{Co}$ and $\mathrm{Nb}$ have low distribution pattern in comparison to $\mathrm{Sr}, \mathrm{Zr}, \sum$ (HREE)n and $\sum$ (REE)n (Fig. 6).

The alkaline condition and predominance of fine-grained size particles provide larger surface area rich in organic and hydroxide coatings of the stream sediments contributed to the transportation and subsequent deposition of the trace elements (Ramesh et al., 2000). The variation in concentration patterns of the trace elements from downstream to upstream suggested probability of geogenic, lithogenic and anthropogenic impact.

\subsection{Multivariate Statistics}

To study the elemental association and factors responsible for their distribution patterns, multivariate statistics involving Pearson correlation of Y, ¿LREE, $\mathrm{H}$ HREE, $\sum R E E, \mathrm{~V}, \mathrm{Cr}, \mathrm{Ni}, \mathrm{Cu}, \mathrm{Zn}, \mathrm{As}, \mathrm{Sr}, \mathrm{Mo}, \mathrm{Rb}, \mathrm{Pb}, \mathrm{Co}, \mathrm{Nb}$ and $\mathrm{Zr}$ was done. The correlation matrix for rare earth and trace elements in the study area is given in Table 6 . Y has negative correlation with REE, LREE, V, Cr, Ni, Zn, Pb but positively correlated with HREE, Sr, Co, Rb, Nb and $\mathrm{Zr}$. $\mathrm{Zn}$ is positively correlated with REE, LREE, HREE, Co, As, Nb, V, Cr and $\mathrm{Ni}$. REE is positively correlated with $\mathrm{V}, \mathrm{Cr}, \mathrm{Ni}, \mathrm{Co}, \mathrm{Zn}$, As and $\mathrm{Nb}$. HREE has positive correlation with Y, V, Zn, Sr, Co, Rb, Nb, Zr, REE and LREE but negatively with $\mathrm{Cr}, \mathrm{Ni}, \mathrm{Co}, \mathrm{As}$ and $\mathrm{Pb}$.

Factor analysis was carried out to group and identify parameters relating the association of REEs and trace elements distribution in the study area. Five factors were initially extracted based on Eigenvalues $>1$ but using scree plot, three component factors were finally extracted at $68.52 \%$ of the population variance. Factor 1 has $\mathrm{Zn}$, LREE, REE, Ni, V, Rb, Zr, Cr, Y, and Pb. Factor 2 consists of Rb, Sr, Zr, Cu, Cr, Y, Pb, HREE, Nb, while Factor 3 is made up of $\mathrm{Zn}, \mathrm{Sr}, \mathrm{Y}, \mathrm{Pb}, \mathrm{HREE}$, As and $\mathrm{Co}$ (Table 7). The principal component analysis using rotation solution revealed three sources of the distribution of REEs and trace elements in the study area. The analyses revealed that $\mathrm{HREE}, \mathrm{Rb}, \mathrm{Zr}, \mathrm{Y}$ and $\mathrm{Nb}$ were derived from geogenic source resulting from weathering, while $\mathrm{Cr}$, Co, $\mathrm{Ni}$ and $\mathrm{Zn}$ are from the geogenic source via adsorption by clay minerals in the stream sediments. On the other hand, LREE, REE, Ni, V, Cr are lithogenic, while $\mathrm{Zn}, \mathrm{Pb}$ and $\mathrm{As}$ have mixed origin of lithogenic and anthropogenic sources.

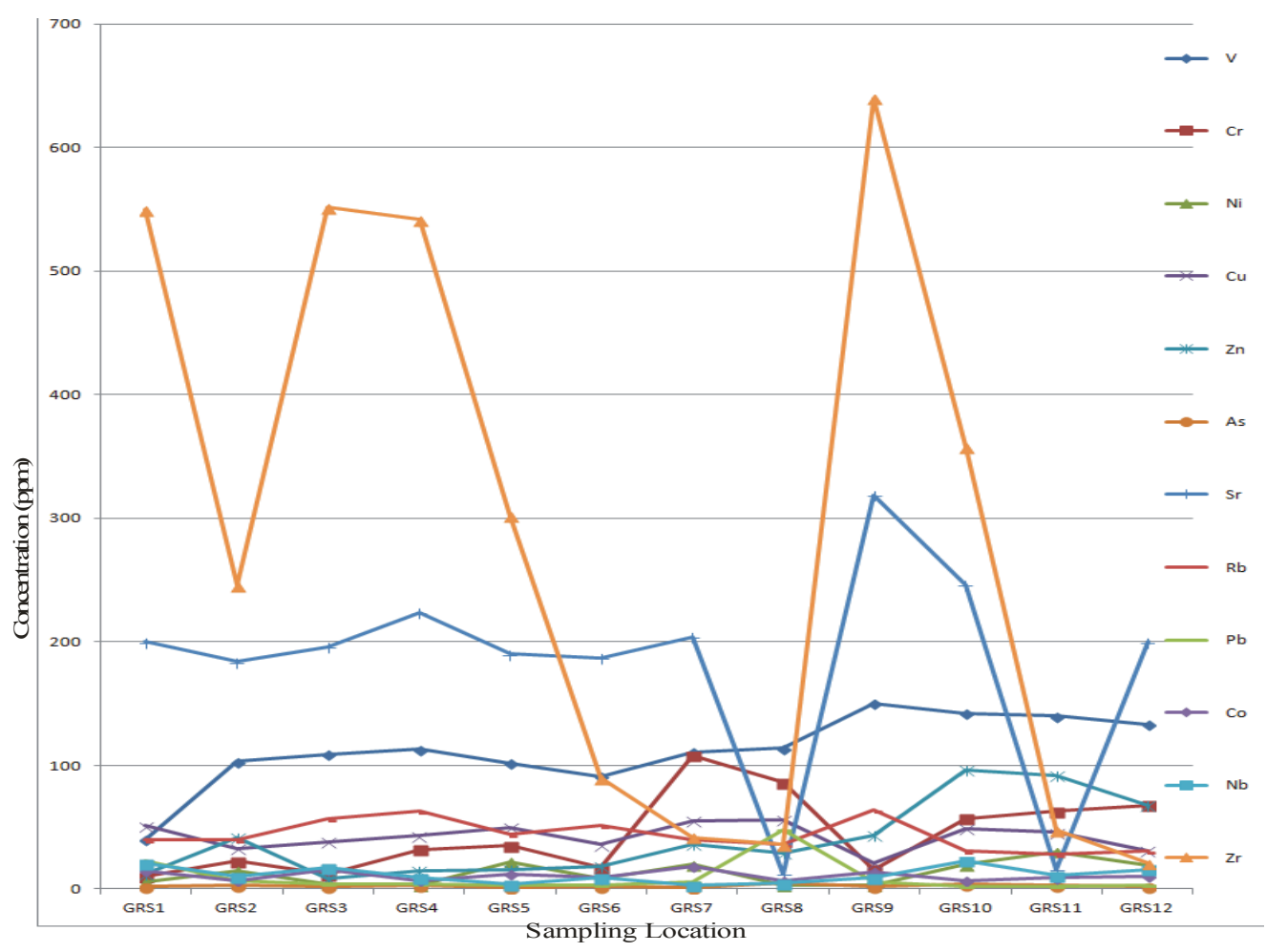

Figure 7. Downstream to Upstream Spatial Distribution of Trace Elements in River Gora Sediments 


\section{Conclusions}

The REE distribution patterns revealed that $\sum$ (HREE)n were more concentrated midstream and upstream than downstream, while $\sum(\mathrm{LREE}) \mathrm{n}$ and $\sum$ (REE)n have their higher concentrations upstream and lowest concentrations downstream. Eu/Eu* has its highest average concentration midstream, while (La/Yb)n has high average values downstream and upstream. $\mathrm{Ce} / \mathrm{Ce} *$ has highest average concentration upstream in comparison to its average downstream values. The enriched REEs are indicative of felsic source rocks. Lower velocity in River Gora may be responsible for the high degree of fractionation between LREEs and HREEs noticed in their distribution. The enrichment of REEs reflects the intense silicate weathering of crustal materials and their subsequent deposition in sediments of the streams. Variation in Ce anomalies is indicative of terrigenous input, depositional environment and diagenetic conditions. The distribution patterns of the trace elements from downstream to upstream suggested geogenic (weathering, erosion, etc), lithogenic and anthropogenic impact. The principal component analysis using rotation solution revealed three sources for the distribution of REEs and trace elements in the study area. The findings from this study will contribute to better understanding of the regional geology and the review of the published map of Minna area in which the occurrence of schist outcrop in the bed and banks of River Gora was not previously captured.

Table 6. Correlation matrix for rare earth and trace elements in sediments from River Gora

\begin{tabular}{|c|c|c|c|c|c|c|c|c|c|c|c|c|c|c|c|c|}
\hline & $\mathrm{Y}$ & $\mathrm{V}$ & $\mathrm{Cr}$ & $\mathrm{Ni}$ & $\mathrm{Cu}$ & $\mathrm{Zn}$ & As & $\mathrm{Sr}$ & $\mathrm{Pb}$ & $\mathrm{Co}$ & $\mathrm{Rb}$ & $\mathrm{Nb}$ & $\mathrm{Zr}$ & REE & LREE & HREE \\
\hline $\mathrm{Y}$ & 1.00 & & & & & & & & & & & & & & & \\
\hline $\mathrm{V}$ & -0.42 & 1.00 & & & & & & & & & & & & & & \\
\hline $\mathrm{Cr}$ & -0.72 & 0.37 & 1.00 & & & & & & & & & & & & & \\
\hline $\mathrm{Ni}$ & -0.52 & 0.31 & 0.46 & 1.00 & & & & & & & & & & & & \\
\hline $\mathrm{Cu}$ & -0.43 & -0.35 & 0.53 & 0.24 & 1.00 & & & & & & & & & & & \\
\hline $\mathrm{Zn}$ & -0.45 & 0.67 & 0.43 & 0.68 & -0.06 & 1.00 & & & & & & & & & & \\
\hline As & -0.38 & 0.25 & 0.20 & -0.18 & 0.21 & 0.35 & 1.00 & & & & & & & & & \\
\hline $\mathrm{Sr}$ & 0.45 & 0.04 & -0.43 & -0.27 & -0.51 & -0.16 & -0.48 & 1.00 & & & & & & & & \\
\hline $\mathrm{Pb}$ & -0.10 & -0.31 & 0.25 & -0.44 & 0.44 & -0.26 & 0.56 & -0.52 & 1.00 & & & & & & & \\
\hline Co & 0.58 & -0.26 & -0.03 & -0.08 & 0.03 & -0.37 & -0.74 & 0.34 & -0.12 & 1.00 & & & & & & \\
\hline $\mathrm{Rb}$ & 0.49 & -0.05 & -0.58 & -0.72 & -0.46 & -0.65 & -0.29 & 0.55 & -0.18 & 0.25 & 1.00 & & & & & \\
\hline $\mathrm{Nb}$ & 0.44 & -0.11 & -0.35 & -0.03 & -0.12 & 0.32 & 0.19 & 0.25 & -0.15 & -0.04 & -0.21 & 1.00 & & & & \\
\hline $\mathrm{Zr}$ & 0.66 & -0.16 & -0.72 & -0.56 & -0.30 & -0.37 & -0.13 & 0.63 & -0.14 & 0.26 & 0.69 & 0.37 & 1.00 & & & \\
\hline REE & -0.25 & 0.44 & 0.58 & 0.42 & 0.20 & 0.66 & 0.12 & -0.13 & -0.23 & 0.06 & -0.40 & 0.29 & -0.32 & 1.00 & & \\
\hline LREE & -0.43 & 0.46 & 0.72 & 0.49 & 0.25 & 0.68 & 0.19 & -0.31 & -0.10 & -0.06 & -0.58 & 0.22 & -0.55 & 0.92 & 1.00 & \\
\hline HREE & 0.37 & 0.04 & -0.21 & -0.08 & -0.06 & 0.10 & -0.14 & 0.39 & -0.36 & 0.33 & 0.34 & 0.24 & 0.49 & 0.40 & 0.01 & 1.00 \\
\hline
\end{tabular}

Table 7. Principal component analysis of samples rotated component matrix

\begin{tabular}{lrrr}
\hline \multirow{2}{*}{ Element } & \multicolumn{3}{c}{ Component } \\
\cline { 2 - 4 } $\mathrm{Zn}$ & \multicolumn{1}{c}{1} & 2 & \multicolumn{1}{c}{3} \\
$\mathrm{LREE}$ & .884 & & \\
$\mathrm{REE}$ & .872 & & \\
$\mathrm{Ni}$ & .860. & & \\
$\mathrm{~V}$ & .768 & & \\
$\mathrm{Rb}$ & -.622 & & \\
$\mathrm{Sr}$ & -.618 & .503 & \\
$\mathrm{Zr}$ & -.500 & .723 & .367 \\
$\mathrm{Cu}$ & & -.706 & \\
$\mathrm{Cr}$ & .627 & -.639 & \\
$\mathrm{Y}$ & -.493 & .569 & .358 \\
$\mathrm{~Pb}$ & -.399 & -.569 & -.421 \\
$\mathrm{HREE}$ & & .565 & .317 \\
$\mathrm{Nb}$ & & .556 & \\
$\mathrm{As}$ & & & -.925 \\
$\mathrm{Co}$ & & & .874 \\
\hline
\end{tabular}




\section{References}

Barat, J., Zanda, B., Moynier, F., Bollinger, C., \& Liorzou, C. et al. (2012).Geochemistry of CI-Chondrites: Major and trace elements and $\mathrm{Cu}$ and $\mathrm{Zn}$ Isotopes. Geochimica et Cosmochimica Acta, 83, 79-92. http://dx.doi.org/10.1016/j.gca.2011.12.011

Black, R. (1980). Precambrian of the West Africa, Episodes, 4, 3-8.

Burke, K. C., \& Dewey, J. F. (1972). Orogeny in Africa, In African Geology, T. F. J. Dessauvagie and A. J. Whiteman (Eds.), Univ. Ibadan, 583-608.

Dada, S. S. (2006). Crust Forming Ages and Proterozoic Crustal Evolution in Nigeria: Re-appraisal of Current Interpretations, Precambrian Research, 65-74.

Gandu, A. H, Ojo, S. B., \& Ajakaiye, D. E. (1986). A Gravity Study of the Precambrian in the Malumfashi Area of Kaduna State, Nigeria. Tectonophysics, 126, 181-191. http://dx.doi.org/10.1016/0040-1951(86)90227-1

Gao, S., Luo, T. C., Zhang, B. R., Zhang, H. F., Han, Y. W., Hu, Y. K., \& Zhao, Z. D. (1975). Chemical composition of the continental crust as revealed by studies in East China, Geochim. Cosmochim. Acta, 62, 1959-1975. http://dx.doi.org/10.1016/S0016-7037(98)00121-5

Grant, K., Rex, D. C, Burke, K. C., \& Freeth, S. J. (1969). The geological sequence and geochronology of old basement rocks from Ibadan, Nigeria, Am. Fac. Sci. Clermom E-Fd 41. Geomineral, Fasc. 19, 84.

Iloeje, N. P. (1991). A new geography of Nigeria, Academy Press Ltd., Lagos, 201.

Key, R. M., Johnson, C. C., Horstwood, M. S. A., Lapworth, D. J., Knights, K. V., Kemp, S. J., ... Arisekola, T. (2012). Investigating high zircon concentrations in the fine fraction of stream sediments draining the Pan-African Dahomeyan Terrane in Nigeria. Appl. Geochem, 27(8), 1525-1539. http://dx.doi.org/10.1016/j.apgeochem.2012.04.009

McLennan, S. M. (1988). Recycling of the continental crust, Pure Appl. Geophys. (PAGEOPHY), 128, 683-724. http://dx.doi.org/10.1007/BF00874553

McLennan, S. M. (1989). Rare earth elements in sedimentary rocks: influence of provenance and sedimentary processes, Rev. Mineral 21, 169-200.

Piper, D. Z. (1974). Rare earth elements in sedimentary cycle: a summary, Chem. Geol., 14, 285-304. http://dx.doi.org/10.1016/0009-2541(74)90066-7

Ramesh, R., Ramanathan, A. L., Ramesh, S., Purvaja, R., \& Subramanian, V. (2000). Distribution of rare earth elements and heavy metals in the surficial sediments of the Himalayan river system. Geochem. Jour., 34, 295-319. http://dx.doi.org/10.2343/geochemj.34.295

Rudnick, R. L., \& Gao, S. (2003). Composition of the continental crust, In: The Crust 3, R. L. Rudnick (ed.), In: Treatise on Geochemistry, Holland, H. D. and Turekian, K. K. (eds.), Elsevier-Pergamon, Oxford, 1-64.

Taylor, S. R., \& McLennan, S. M. (1985). The continental crust: Its composition and evolution. Blackwell, Oxford.

Taylor, S. R., \& McLennan, S. M. (1995). The geochemical evolution of the continental crust, Rev. Geophys. 33, 241-265. http://dx.doi.org/10.1029/95RG00262

Toyoda, K., Nakumara, Y., \& Masuda, A. (1990). Rare earth elements of Pacific pelagic sediments, Geochim. Cosmochim. Acta, 54, 1053-1103. http://dx.doi.org/10.1016/0016-7037(90)90441-M

Wedepohl, H. (1995). The composition of the continental crust, Geochim. Cosmochim. Acta, 59, 1217-1239. http://dx.doi.org/10.1016/0016-7037(95)00038-2

\section{Copyrights}

Copyright for this article is retained by the author(s), with first publication rights granted to the journal.

This is an open-access article distributed under the terms and conditions of the Creative Commons Attribution license (http://creativecommons.org/licenses/by/3.0/). 